\title{
An Assessment of the Psychosocial Effects of Almajiri system on Child's Development in Gwange Ward Maiduguri, Borno State, Nigeria
}

\author{
Article by Emmanuel O. Chukwu ${ }^{1}$, Habu Haruna ${ }^{2}$ and Terna M. Fiase ${ }^{3}$ \\ ${ }^{1,3}$ School of Nursing Mkar, Gboko, ${ }^{2}$ Department of Nursing Science, College of \\ Medical Sciences, University of Maiduguri, Nigeria \\ E-mail: emmanwaguy42@yahoo.com
}

\begin{abstract}
Children are known to be the source of joy in every family especially when the parents can afford their basic needs. Children in the northern part of Nigeria are prone to deprivation through almajiri system of education mainly due to respect for misunderstood religious concept and culture among other causes. This study of psycho-social effects of almajiri system on child's development was conducted in Gwange ward, Maiduguri, is aimed at identifying the psychological effects of almajiri system on child's development as well as the social effects of almajiri system on child's development. A descriptive design was used for the study. Data was obtained from respondents (almajiris) using structured questionnaire. The data was presented and analysed using descriptive statistics. Hypotheses were formulated and tested using Chi-square. The findings of this study revealed that the almajiris are affected both psychologically and socially due to lack of adequate care, loneliness, feeling of anger, lack of proper feeding and security, exposure to dangers and negligence by the society. Based on these findings, community health workers, psychologists, sociologists and government should be in the fore front of taking care of the almajiri system. Recommendations were made to families, communities, government and Non Governmental Organisation's on ways of improving the system and incorporating it with western education.
\end{abstract}

Keywords: psychosocial, effects, almajiri, development

\section{Introduction}

The Almajiri system is a traditional system of education associated with Islamic education practiced in some parts of Africa and Asian countries (especially the Muslim dominated countries). The word "Almajiri” emanated from an Arabic word "Al-muhajjirun" meaning "emigrants" describing someone who leaves his home in search of knowledge in Islamic religion (Kabiru, 2012). The almajiri system of education as practiced today in northern Nigeria is seriously abused as evidenced by the conditions under which the system is operating. Today, the word Almajiri has acquired a completely new meaning; it is mostly referred to as beggars roaming the street in our towns and cities. They are seen swarming the streets of northern Nigeria like locusts begging for alms in order to sustain themselves and their mallams (Obioha, 2009; Thinkquest, 2010). The almajiri who is thought to be a pious pupil in search of knowledge became rather a social problem in the society. They practically, depend on people for their food and other life needs (Ibrahim, 2008). In the course of begging on the streets, they are exposed to various forms of hazards and situations. Begging for food took most of his time instead of learning, Yahaya (2004). This is in contrast with Federal Government of Nigeria (2004) proclamation which state that 'every Nigerian child shall has a right to equal educational opportunities irrespective of any real or imagined disabilities'.

Several factors can be associated with the poor organizational structures of the Almajiri system of education. These factors may include but not limited to: high striking poverty line in the families to take care of their children's basic needs, (Bello, 2006). Nura,(2010) reported that Almajiri's sleep on worn out mats and sometimes up 30 Almajiris sleep in a room that is not well ventilated, making them vulnerable to all forms of airborne infections and other 
Texila International Journal of Public Health

Volume 4, Issue 4, Dec 2016

diseases while some sleep in uncompleted buildings or by the roadside. Shagari. F (2009) equally opined that the Almajiri system was originally designed to give children Qur'anic knowledge but the structure has been changed as the Almajiri child is seen only as a begging street child. Some Mallams do not even allow their children to mingle with the Almajiris to the extent that they allow their own children to attend formal school. The Almajiris are exploited by their mallams, which include going to farm, fetching water for his domestic use, collecting fire wood and sometimes bringing back the proceed from begging, this affects psychological and physical development of a child (Kano State Government, 2012).

Begging is one of the most disturbing social ills of our time and Parents are becoming so insensitive to the welfare of their children that they dispatch them to unknown places to take care of themselves without making any arrangement for their feeding, medical care, shelter and other necessities of life (Dukku, 2009). Sadly, the economic hardship is taking its toll on the almajiri's as they hardly get left over, and so, they resorted to doing menial jobs like nail cutting, cap weaving cobbling to feed, Yaro Boys etc. The begging and menial jobs proceeds are used to sustain themselves and their teachers (Malams).

Kopoka. A. (2000) pointed out that children involved in begging run enormous risks, often darting between cars in heavy traffic begging for alms with a high risk of accidents. Most of these children are seen roaming the streets hopelessly and helplessly begging for alms to survive and because of the harsh realities they find themselves in end up becoming juvenile delinquents and subsequently adult criminals. Child beggars suffer severe psycho-social consequences of being exposed to constant abuse and aggression from the general public. They spend greater part of their formative years like forgotten refugees in their own country struggling, hustling and suffering, (Hassan \& Moses 2010).

Attitude of the society towards the almajiris is a complete paradox; some treat them with contempt and exploit them while others give them alms and food out of sympathy or after using them to run errands. They are left to scavenge for food remnants. Social psychologists noted that when a child is exposed to labor at a teenage age and deprived basic needs or no benefit and entertainment, such child normally develop the habit of loneliness and this may lead to schizophrenia. In an effort to capture the plight of the almajiris Abdullahi (2011) lamented that the almajiris endure utter deprivation, and their appearances leave much to be desired. With their unkempt hair, dirty faces, blistered lips, tainted teeth, crusty skin, stinking bags and bare feet; they are distinctive. Armed with plastic bowls, decorated with shabby attires, and congregated into small groups, they accost members of the public with alluring songs and soliciting alms. Almajiris are vulnerable to being used as political thugs by benefactors who take advantage of their lack of formal education. They are considered as great security risks as many of them have become miscreants who actively participate in ethnic, religious and political violence and terrorism (Christian, 2010). Therefore, children's rights such as right to education, health, entertainment, association, interaction, shelter and nutrition must be protected, preserved and maintained. Once these essential needs are provided, there is no doubt that they can perform wonderfully in their undertaking as leaders of tomorrow. It is unfortunate that at the age of four, a child is taken somewhere else to fend for self in terms of feeding, accommodation, clothing and medicament. The vulnerability of these almajiris made them handy for criminal activities including terrorism as they were already antagonistic to western culture and opposed to society which has failed to treat them well, (Peace, 2012).

\section{Statement of the problem}

The number of Almajiri's seen roaming the streets of Maiduguri is increasing by day and this has become a subject of concern to the researchers and other well meaning Nigerians. According to Kano State Ministry of Education Statistics as cited by Abdulrafiu (2009); Borno is reputed as a center of Islamic learning having 389,048 Almajiri's with 4,468 Tsangayas (Almajiri schools) with indigenes: 266,160 while from other states 118,280. Non Nigerians 4,608 and yet the figure is not conclusive as the Almajiri census is still ongoing. 
The system is growing in a geometrical progression turning it into modern slavery and worst of all affecting the child's development in all forms.

The Almajiri's are seen swarming the streets of Borno and other states in the country especially Northern states like locusts. They are mostly seen with bowls in their hands in a sorry looking state, usually very dirty and in tattered clothes. They sleep on worn out mats in a room where about 25 of them live with no proper ventilation making them vulnerable to all forms of air borne infections and other diseases associated with the harsh Maiduguri weather. Most of these children because of the harsh realities they find themselves in end up becoming criminals and burden to the society instead of social and spiritual assets.

Therefore, this research is aimed at assessing the psychosocial effects of Almajiri system of education on child's development with view to finding useful information that will guide policymakers in decision making regarding Almajiri system of education.

\section{Objectives of the Study}

The specific objectives of the study are:

1. To identify the psychological effects of Almajiri system on child's development.

2. To explore the social effects of Almajiri system on child's development.

\section{Hypothesis}

1. There is no significant difference between the number of children in the family the Almajiri's child comes from and the care of the Almajiri child.

2. There is no significant difference between separation of child from parents and how the Almajiri child feels.

3. There is no significant difference between the environment the Almajiris live in and their security needs.

\section{Method}

\section{Study design}

A descriptive survey design was used for this study because it deals with accurate and factual description and the summary of the actual situation.

\section{Study setting}

The research work was conducted in Gwange wards 1 and 2 of Maiduguri. Gwange was created in 1975 by Baba Gwange, later developed into Gwange 1, 2, 3 wards. These wards are headed by the district head called Alhaji Zanna Mai Jir. Gwange 1 is further divided into 5 units and each is headed by a Bulama. Generally, the predominant inhabitants are traders, truck drivers, bricklayers and embroider. The custom and tradition of the residents are highly influenced by Islam. The population is multiethnic. Gwange ward as the area of study is one of the area where Almajiri System of Education is highly practiced.

\section{Study population and sampling technique}

Convenient sampling method was used to select 150 almajiris used for this study; 6 schools were picked out of 46 schools found in Gwange I while 9 schools were picked out of the 52 schools found in Gwange II using simple random sampling technique. Ten (10) almajiris from each of the 15 schools chosen from Gwange I and II made up the selected 150 almajiris as earlier mentioned.

\section{Instrumentation}

A structured questionnaire was formulated by the researchers which was translated into Hausa language. The instrument validated by expert where content validity index was computed and the result obtained was 0.81 which indicated the instrument validity. Ten copies of the questionnaire were pre-tested at Mairi Kuwait, Jere LGA, Borno State using test retest method to ensure consistency and reliability of the instrument. Reliability coefficient of 
Texila International Journal of Public Health

Volume 4, Issue 4, Dec 2016

0.75 was obtained which made it right for the study. The questionnaire included three sections. Section A was for demographic data of almajiris, section B was about the psychological effects of almajiri system and section $C$ was about the social effects of almajiri system.

\section{Procedure for data collection}

The researchers obtained an ethical approval from the District Head of Gwange.150 respondents were selected over the period one month. Informed consent was obtained from the respondents. The questionnaire was translated into Hausa language to the respondents for data collection. The researchers trained additional three people who assisted in data collection (by using the checklist; asking them and filling the appropriate options).

\section{Method of data analysis}

Data was analyzed after collection by the researchers using descriptive and inferential statistics (simple frequencies, percentages and chi-squares was used for testing the relationship at 0.05 level of significance). All data were presented in tab

\section{Findings}

Table (1). socio demographic data

\begin{tabular}{|l|l|l|}
\hline Age & Frequency & Percentage (\%) \\
\hline $5-9$ & 37 & 24.67 \\
\hline $10-14$ & 62 & 41.33 \\
\hline 15 and above & 51 & 34 \\
\hline Total & 150 & 100 \\
\hline State of origin of almajiris & & \\
\hline Borno & 62 & 41.33 \\
\hline $\begin{array}{l}\text { Other Northern States in } \\
\text { Nigeria }\end{array}$ & 64 & 42.67 \\
\hline Not from Nigeria & 24 & 16 \\
\hline Total & $\mathbf{1 5 0}$ & $\mathbf{1 0 0}$ \\
\hline $\begin{array}{l}\text { Number in the family of } \\
\text { almajiris }\end{array}$ & & \\
\hline$<5$ & 21 & 14 \\
\hline $5-10$ & 65 & 43.33 \\
\hline$>10$ & 38 & 25.33 \\
\hline 15 and above & 26 & 17.33 \\
\hline Total & $\mathbf{1 5 0}$ & $\mathbf{1 0 0}$ \\
\hline $\begin{array}{l}\text { Type of family the Almajiri } \\
\text { child comes from }\end{array}$ & & \\
\hline Monogamy & 53 & 35.33 \\
\hline Polygamy & 97 & 64.67 \\
\hline Total & $\mathbf{1 5 0}$ & $\mathbf{1 0 0}$ \\
\hline Tribe of almajiri & 63 & 31.33 \\
\hline Kanuri & & 42 \\
\hline Hausa/Fulani & \\
\hline & & \\
\hline
\end{tabular}




\begin{tabular}{|l|l|l|}
\hline Babur & 11 & 7.33 \\
\hline Shuwa Arab & 12 & 8 \\
\hline Others & 17 & 11.33 \\
\hline Total & $\mathbf{1 5 0}$ & $\mathbf{1 0 0}$ \\
\hline
\end{tabular}

Table I shows that respondents from age 10 - 14 years were the majority with 62 (41.33\%) followed by 15 and above years with 51(34\%) and lastly $5-9$ with $57(24.67 \%)$.

The table equally also shows that $64(42.67 \%)$ of the respondents were from other Northern States in Nigeria, 62(41.33) were from Borno and 24(16\%) were non-Nigerians.

On the respondents' numbers in their family, 5 - 10 were 65(43.33\%), >10 38(25.33\%) while 15 and above 26 (17.33\%). 97(64.67\%) of the respondent were from polygamous family and 53(35.33\%) were from monogamous family.

Ethnicity distribution shows that Hausa/Fulani has the highest frequency among the Almariris with 63(42\%) followed by Kanuri with47 (31.33).

Table (2). Do the almajiri receive adequate care?

\begin{tabular}{|l|l|l|}
\hline Variables & Frequency & Percentage (\%) \\
\hline Yes & 43 & 28.67 \\
\hline No & 107 & 71.33 \\
\hline Total & 150 & 100 \\
\hline
\end{tabular}

Table 2 shows that $43(28.67 \%)$ receive adequate care while $107(71.33 \%)$ do not receive adequate care.

Tables (3). Psychological effects of Almajiri system

\begin{tabular}{|c|c|c|c|c|c|c|}
\hline \multirow{3}{*}{$\begin{array}{l}\text { Questions } \\
\text { Questions }\end{array}$} & \multicolumn{4}{|l|}{ Variables } & \multirow{2}{*}{\multicolumn{2}{|c|}{ Total }} \\
\hline & \multicolumn{2}{|l|}{ Yes } & \multicolumn{2}{|l|}{ No } & & \\
\hline & Frequency & $\%$ & Frequency & $\%$ & Frequency & $\%$ \\
\hline $\begin{array}{l}\text { Do you stay with your } \\
\text { parents? }\end{array}$ & 41 & 27.33 & 109 & 72.67 & 150 & 100 \\
\hline $\begin{array}{l}\text { If no, are you disturbed } \\
\text { as a result of separation } \\
\text { from your parents? }\end{array}$ & 99 & 66 & 51 & 34 & 150 & 100 \\
\hline $\begin{array}{l}\text { Are you bullied or } \\
\text { maltreated by your } \\
\text { malams or seniors? }\end{array}$ & 89 & 59.3 & 61 & 40.67 & 150 & 100 \\
\hline $\begin{array}{l}\text { Do you feel lonely and } \\
\text { angry as a result of the } \\
\text { system? }\end{array}$ & 110 & 73.33 & 40 & 26.67 & 150 & 100 \\
\hline
\end{tabular}

Table 3 shows that the respondents that stay with their parents are 41(27.33\%) and 109(72.67\%) do not. Those that are disturbed as a result of separation from their parents are 99(66\%) while 51(34\%) are not. On bullying or maltreatment by their Malams 86(59.3\%) acknowledged while 61(40.67\%) said no. Those that feel lonely and angry as a result of the system are $110(73.33 \%)$ while those are not $40(26.67 \%)$.

Table (4). How does the Almajiri Child feels about the system

\begin{tabular}{|l|l|l|}
\hline Variables & Frequency & Percentage (\%) \\
\hline Happy & 40 & 26.67 \\
\hline Sad & 110 & 73.33 \\
\hline Total & 150 & 100 \\
\hline
\end{tabular}


Texila International Journal of Public Health

Volume 4, Issue 4, Dec 2016

Table 4 shows that 40 (26.67\%) of the respondents are happy about the system while $110(73.33 \%)$ are sad.

Table (5). Places where Almajiris live and sleep at night (Social effects).

\begin{tabular}{|l|l|l|}
\hline Variables & Frequency & Percentage (\%) \\
\hline In a building & 80 & 53.33 \\
\hline In an open environment & 62 & 41.33 \\
\hline On the street/by the roadside & 8 & 5.33 \\
\hline Total & 150 & 100 \\
\hline
\end{tabular}

Table 5 Shows that those who live and sleep in a building have the highest score of 80(53.33\%) followed by those who sleep in an open environment 62(41.33\%) and lastly those who sleep on the street/by the road side are 8(5.33\%).

\begin{tabular}{|c|c|c|c|c|c|c|}
\hline \multirow{3}{*}{$\begin{array}{l}\text { Questions } \\
\text { Questions }\end{array}$} & \multicolumn{4}{|l|}{ Variables } & \multirow{2}{*}{\multicolumn{2}{|c|}{ Total }} \\
\hline & \multicolumn{2}{|l|}{ Yes } & \multicolumn{2}{|l|}{ No } & & \\
\hline & Frequency & $\%$ & Frequency & $\%$ & Frequency & $\%$ \\
\hline $\begin{array}{l}\text { Do you normally have } \\
\text { regular meals? }\end{array}$ & 59 & 39.33 & 91 & 60.67 & 150 & 100 \\
\hline $\begin{array}{l}\text { Do you think you are } \\
\text { safe and secured where } \\
\text { you live or stay? }\end{array}$ & 47 & 31.33 & 103 & 68.67 & 150 & 100 \\
\hline $\begin{array}{l}\text { Would you like to go for } \\
\text { western education? }\end{array}$ & 95 & 63.33 & 55 & 36.67 & 150 & 100 \\
\hline $\begin{array}{l}\text { Do you feel neglected } \\
\text { by the society? }\end{array}$ & 103 & 68.67 & 47 & 31.33 & 150 & 100 \\
\hline
\end{tabular}

Table (6). Social effects

Table 6 shows the respondents that have regular meals as 59(39.33\%) while those that do not have are with highest frequency of 91(60.67\%). Those that think they are safe and secured where they live or stay are $47(31.33 \%)$ while those that think they are not safe and secured 103(68.67\%). 95(63.33\%) of the respondents would like to go for western education while 55(36.67\%) would not. Those that feel they are neglected by the society are 103(68.67\%) while those that feel they are not are 47(31.33\%).

\section{Testing of hypothesis}

Research hypothesis were tested using chi square $\left(\mathrm{x}^{2}\right)$ at 0.05 level of significance are as follows:

1. There is no significant difference between the number of children in the family the Almajiri child comes from and the care of the Almajiri child receives

Hypothesis table (1): There is no significant difference between the number of children in the family the Almajiri child comes from and the care of the Almajiri child.

\begin{tabular}{|l|l|l|l|l|l|}
\hline & \multicolumn{6}{|l|}{ Number of Almajiris in their family } \\
\hline Care they receive & $<\mathbf{5}$ & $\mathbf{5 - 1 0}$ & $\mathbf{1 0}$ & $\mathbf{1 5}$ and above & Total \\
\hline Adequate care & $21(14.98)$ & $58(46.37)$ & $28(27.11)$ & $0(18.55)$ & 107 \\
\hline No adequate care & $0(6.0)$ & $7(18.63)$ & $10(10.90)$ & $26(7.45)$ & 43 \\
\hline Total & 21 & 65 & 38 & 26 & 150 \\
\hline
\end{tabular}

$\left(\mathrm{x}^{2} \mathrm{c}(83.46)>\mathrm{x}^{2} \mathrm{~T}\right.$ (7.815), $\mathrm{df}=3, \mathrm{p}=0.050$..

The calculated $x^{2}$ is 83.46 while the tabulated value of $\left.x^{2} 7.815\right)$, $d f=3, p=0.050$.

Since the calculated of value $x^{2}$ is greater than tabulated value of $x^{2}$, the null hypothesis is rejected. By rejecting the null hypothesis, we therefore, conclude that there is a significant 
relationship between the number of children in the family the Almajiri child comes from and the care Almajiri child receives.

Hypothesis table (2): There is no significant difference between separation of child from parents and how the Almajiri child feels.

\begin{tabular}{|l|l|l|l|}
\hline & \multicolumn{3}{|l|}{ Separation of almajiri child from parents } \\
\hline $\begin{array}{l}\text { How the almajiri } \\
\text { child feels }\end{array}$ & With parents & Without parents & Total \\
\hline Happy & $15(10.93)$ & $25(29.1)$ & 40 \\
\hline Sad & $26(30.06)$ & $84(80)$ & 110 \\
\hline Total & 41 & 109 & 150 \\
\hline
\end{tabular}

$\left(\mathrm{x}^{2} \mathrm{c}(2.85)<\mathrm{x}^{2} \mathrm{~T}(3.842), \mathrm{df}=1, \mathrm{p}=0.050\right.$.

The calculated $x^{2}$ is 2.85 while the tabulated value of $x^{2} 3.842$, $d f=1, p=0.050$.

Since the calculated of value $x^{2}$ of less than tabulated value of $x^{2}$, the null hypothesis is accepted. By accepting the null hypothesis, we therefore, conclude that there is no significant relationship between separations of child from parents and how the Almajiri child feels.

\section{Discussion of findings}

\section{Psychological effects of almajiri system on child's development}

The findings of this study showed that 41(27\%) Almajiris stay with their parents while 109 (73\%) do not. 99(66\%) of Almajiris were disturbed while 51 (34\%) feel okay. This finding is in accordance with Dukku (2009) who reported that parents are becoming insensitive to the welfare of their children that they dispatch them to unknown places to take care of themselves. Also Encyclopedia Britannica (2005) opined that the Almajiris are isolated from their parents, taken to places mostly far away from their parents as such when they see other children in the company of their parents they always feel depressed and rejected. This implies that when a child is deprived of intimate parental care, such a child can potentially be disturbed, depressed and may feel rejected by his parents and the society at large.

The result of the study equally showed that the Almajiris who are bullied or maltreated by their Malams or seniors were 89 (59\%) whiles those who are not $61(41 \%)$. This is in accordance with Tafida (2008) who reported that Malamsare unable to cater for the Almajiris needs send them to do menial jobs and begging. This implies that the mallams and the seniors Almajiris take advantage to ask them to beg and where failure to deliver on such assignment could be problematic for the Almajiris in question.

On the loneliness and angry feelings by the Almajiris, the result showed that 110(73\%) Almajiris feel lonely and angry while $40(27 \%)$ do not. This is again, in agreement with social psychologists thought which noted that when a child is exposed to labour at a teenage and deprived of little or no benefit and entertainment, such child have high risk of developing the habit of loneliness or introvert behaviours in future.

\section{Social effects of Almajiri system on child's development}

On the social effects, the results showed that, 80(53\%) of Almajiris live and sleep in a habitable building, 62(41\%) live in an open environment, 8(5\%) stay on the streets/by the roadside. This finding corresponds with Nura (2010) who reported that the Almajiris sleep on worn-out mats, with about 30 of them sleep in a room without good ventilation while some of them sleep in uncompleted buildings or even by the roadsides. This situation signifies disconnect between the intention (knowledge) and reality on the ground. Therefore, for the intention to be fully achieved, the anomalies associated with the system must be addressed.

The result also Showed that 59(39\%) of the respondents have normal regular meals while 91(61\%) do not. This is in line with Nura (2010) who opined that the economic hardship in the country is taking its roll on the Almajiris as they hardly get leftovers rather they had resorted to doing menial jobs to feed. 
Texila International Journal of Public Health

Volume 4, Issue 4, Dec 2016

On the question of whether the Almajiri feel neglected by the society, 103(69\%) feel neglected while $47(31 \%)$ do not feel neglected. This finding is in concordance with Tafida (2008) who reported the Almajiris are regarded as outcasts, public nuisance and social miscreants by the society. This is supported by UNICEF (2001) that child beggars suffer severe psychosocial consequences for being exposed to constant abuse and aggression from the general public.

\section{Conclusion}

Majority of the respondents are affected psychologically and socially as a result of the Almajiri System. This is due to lack of adequate care, feeling of anger and loneliness, lack of proper feeding, exposure to dangers, lack of proper security and being neglected by the society. Many of the Almajiris would want to go for western education if given the opportunity.

\section{Recommendation}

Recommendations and suggestion were proffered on the ways of improving the Almajiri system. Since it is both a matter of religion and culture which existed for decades uprooting it is certainly not the best option but improving it.

- Community health workers should involve the community through mobilization and health education on the effects of poorly organized Almajiri system education on child's development.

- Mass sensitization campaign to enlighten the society on the dangers of the abuse of system.

- Government and other stakeholders should identify the areas where the almajiri system is still prevalent and co-ordinate the activities of the malams inline with modern Qur'anic learning (Islamiyya) which will broaden the knowledge of the students on Qur'anic education.

- Government should explore all the possibilities of co-opting and integrating the identified Almajiri education centers into compulsory universal basic education (UBE) scheme while retaining the religious content.

- Community health workers should educate their client/patient on the importance of child spacing.

- National and State Assemblies should enact laws that will provide for proper structuring and positioning of the almajiri system.

- Poverty alleviation and mass literacy skills should be pursued vigorously with to improving the standard of the almajiri system.

- Government should collaborate with nongovernmental organizations in the mobilization and integration of the Almajiri system with the western education system.

\section{References}

[1]. Abdulrafiu, L, (2009). Almajiri-Breeding Future Terrorists. Tell, magazine. Available at www.citizensfornigeria.com/index.php/action/item/617-almajiri. Accessed on 20/06/2015.

[2]. Abdullahi, M. (2011) The Almajiris : Nigeria Child Beggars 2011. Available at www.thealmajiris-nigerias-child-beggar Accessed on 20/07/2015.

[3]. Bello, A. (2006) the almajiri syndrome: religion, culture or menace. Expert from paper presented, Kano Nigeria

[4]. Christian, Pure foy (2010). Nigeria's Almajiri Children: Learning a Life of Poverty and Violence. Education Data for Decision Making. Abuja.

[5]. Dukku, A.(2009): Almajiri- 10million kids begs in the north. Available at www.nairaland.com Accessed on 15/08/2015.

[6]. Federal Government of Nigeria (2004). National Policy on Education. Lagos: NERDC Press 
[7]. Hassan, I\& Moses, A.(2010). From to Madarassa: The transformation of Almajiri. Gbooza Mobile. Available at www.gbooza.com/m/discussion. Accessed on 23/08/2015.

[8]. Ibrahim, S. (2008). Menace of street begging in Kano State. Available at http://www.nationaldalies.org Accssed on 14 ${ }^{\text {th }}$ June, 2014.

[9]. Kabiru I. (2012). The north and almajiri phenomenon. Available at www.gamji.com/article8000/NEWS8282.htm

[10]. Kano State Government (2012) Report of Committee on Almajiris.

[11]. Kopoka, A. (2000). The problem of street children in Africa (A paper presented at the international Conference on Street Children and Street Children's Health in East Africa, Held in Darees-sala, Tanzania.

[12]. Nura. M.(2010) Almajiri- breeding of future terrorists. Available at www.nairaland.com. Accessed on 10 August, 2015.

[13]. Obioha, E. (2009) Becoming a Street Child in Poverty Ridden Society: A Descriptive Case of Kaduna Metropolis, Nigeria. Journal of Social Sciences, 19, 41 -49.2009

[14]. Peace, U. (2012). The Need to Remodel Almajiri System in Nigeria. Available at http://desertherald.com/?p=1434. Accessed on 12/12/2014.

[15]. Tafida U.A. (2008). lead debate on the almajiri bill for establishment of the national commission for the eradication of child destitute. Blogspot.com

[16]. Think Quest (2010). Child Abuse in Nigeria. Available at http://library.thinkquest.org/06aug/00168/history.html. Accessed on 12/12/1014

[17]. Yahaya Suleiman (2004). The Amajirai and the Rights of the Child to Education Towards Sustainable Development: Education for Sustainable Development in Nigeria, A book of Readings Vol. 1. Minna : Niger State College of Education. 